\title{
GLOSA
}

\section{Nieważność uchwały rady nadzorczej spółki akcyjnej — glosa do wyroku Sądu Najwyższego z 5.10.2017 r. (I PK 287/16)}

\author{
Invalidity of a resolution of the supervisory board of a joint-stock \\ company - a gloss to the judgment of the Supreme Court \\ of 5 October 2017 (I PK 287/16)
}

\section{dr Aleksandra Sikorska-Lewandowska}

E-mail: as1@umk.pl,nr ORCID 0000-0002-3234-2502

\begin{abstract}
Streszczenie
Przedmiotem glosy jest wyrok Sądu Najwyższego, Izby Pracy, Ubezpieczeń Społecznych i Spraw Publicznych z 5.10.2017 r., w którym oddalono skargę kasacyjną powoda — byłego członka zarządu spółki akcyjnej — w przedmiocie powództwa o zasądzenie odprawy z tytułu rozwiązania stosunku pracy na skutek stwierdzenia, że aneks do umowy o pracę był nieważny, gdyż został zawarty na podstawie nieważnej uchwały rady nadzorczej spółki kapitałowej. Powyższe orzeczenie Sądu Najwyższego zasługuje na pełną aprobatę, w tym, w szczególności, stwierdzenie nieważności uchwały rady nadzorczej spółki kapitałowej, podjęte przy rozstrzyganiu powództwa ze stosunku pracy opartego na aneksie do umowy o pracę zawartym na podstawie uchwały rady nadzorczej.
\end{abstract}

Słowa kluczowe: uchwała rady nadzorczej spółki akcyjnej, nieważność uchwały, rada nadzorcza

\section{Summary}

The subject of the gloss is the judgment of the Supreme Court, Chamber of Labour, Social Insurance, and Public Affairs of 5 October, 2017, which dismissed the cassation of a complaint of a plaintiff, a former member of the management board of a joint-stock company, regarding an action to pay severance pay for termination of employment. This dismissal was owing to the fact that the annex to the employment contract was invalid, because it was concluded on the basis of an invalid resolution of the supervisory board of a company. The above decision of the Supreme Court deserves full approval, including, in particular, the ascertainment of invalidity of the resolution of the supervisory board of a company, taken at the settlement of an action regarding an employment relationship based on an annex to the employment contract, entered into on the basis of a resolution of a supervisory board.

Key words: resolution of supervisory board of a join-stock company, invalidity of resolution, supervisory board

JEL: K2, K22

Str. 27-33 


\section{Bibliografia}

Bielecki, M. (2005). Zasada kolegialnej reprezentacji spółki akcyjnej przez radę nadzorczą w umowach z członkami zarządu. Przegląd Prawa Handlowego, (3), 37-44.

Bilewska, K. (2010). Przesłanki powzięcia uchwały rady nadzorczej spółki kapitałowej a jej zaskarżanie. Monitor Prawniczy (6), 303-311.

Cern, G. (2010). Uchwały „nieistniejące” czy nieważne lub zaskarżalne? W: M. Modrzejewska (red.). Prawo handlowe XXI wieku, czas stabilizacji, ewolucji czy rewolucji, Księga pamiątkowa ku czci Profesora Józefa Okolskiego (69-76). Warszawa: Wolters Kluwer.

Czerniawski, R. (2004). Kodeks spótek handlowych, przepisyo spótce akcyjnej. Komentarz. Warszawa: Dom Wydawniczy ABC.

Gutowski, M. (2012). Nieważność czynności prawnej. Warszawa: C.H. Beck.

Kidyba, A. (2017). Kodeks spótek handlowych (t. 2). Komentarz do art. 301-633. Warszawa: Wolters Kluwer.

Kruszyński, M. (2008). Uchwały nieistniejące. Przegląd Prawa Handlowego, (7), 44-51.

Krysik, A. (2018). W: Z. Jara (red.). Kodeks spótek handlowych. Komentarz. Warszawa: C.H. Beck.

Krzekotowska, K. (1986). Charakter prawny uchwał walnego zgromadzenia spółdzielni a uchylenie się od skutków prawnych oświadczenia woli. Palestra (12), 38-45.

Łętowska, E. (2013). Sankcje w prawie cywilnym — zarys problemu. Monitor Prawniczy, (19), 1016-1023.

Marszałkowska-Krześ, E. (1998). Charakter prawny uchwały. Przegląd Prawa Handlowego, (6), 23-26.

Opalski, A. (2006). Rada nadzorcza w spótce akcyjnej. Warszawa: C.H. Beck.

Piekarski, M. (1960). Wpływ wad głosowania na ważność uchwał walnego zgromadzenia spółdzielni. Nowe Prawo (12), $1604-1611$.

Pinior, P. (2010). Szczególne sposoby podejmowania uchwał przez radę nadzorczą. W: M. Modrzejewska (red.). Prawo handlowe XXI wieku, czas stabilizacji, ewolucji czy rewolucji, Księga pamiątkowa ku czci Profesora Józefa Okolskiego (779-793). Warszawa: Wolters Kluwer.

Popiołek, W. (2013). W: J. A. Strzępka (red.). Kodeks spółek handlowych. Komentarz. Orzecznictwo. Warszawa: C.H. Beck.

Radwański, Z. (2008). W: Z. Radwański (red.). System Prawa Prywatnego (t. 2). Prawo cywilne - część ogólna. Warszawa: C.H. Beck.

Rodzynkiewicz, M. (2014). Kodeks spótek handlowych. Komentarz. Warszawa: Lexis Nexis.

Romanowski, M. (2011). Kilka uwag praktycznych na temat koncepcji uchwał nieistniejących. Monitor Prawniczy, (6), $342-344$.

Saczywko, M. (2014). Sprzeczność uchwały rady nadzorczej z umową albo statutem spółki kapitałowej. Przegląd Prawa Handlowego, (12), 49-53.

Sikorska-Lewandowska, A. (2012). Zarzut nieważności uchwały zgromadzenia wspólników. Glosa, (2), 64-70.

Sikorska-Lewandowska, A. (2013a). Sankcje wadliwych uchwał rad nadzorczych spótek kapitałowych i spółdzielni. Toruń: TNOiK.

Sikorska-Lewandowska, A. (2013b). Sprzeczność uchwały rady nadzorczej ze statutem spółki lub spółdzielni. Przegląd Prawa Handlowego, (11), 42-46.

Sobolewski, P. (2009). Kontrowersje wokół pojęcia nieistnienia i nieważności czynności prawnej. Przegląd Prawa Handlowego, (5), 30-38.

Sołtysiński, S. (2006). Czy „istnieją” uchwały „nieistniejące” zgromadzeń spółek kapitałowych. Przegląd Prawa Handlowego, (1), 4-15.

Sołtysiński, S. (2007). Rozważania o nieważnych i „nieistniejących” czynnościach prawnych ze szczególnym uwzględnieniem uchwał zgromadzeń spółek kapitałowych i spółdzielni. W: A. Brzozowski, W. Kocot, K. Michałowska (red.). W kierunku europeizacji prawa prywatnego. Księga pamiątkowa dedykowana profesorowi Jerzemu Rajskiemu (305-326). Warszawa: C.H. Beck.

Sołtysiński, S. (2010). W: S. Sołtysiński (red.). System Prawa Prywatnego (t. 17B). Prawo spółek kapitałowych. Warszawa: C.H. Beck.

Sołtysiński, S., Opalski, A. (2010). Zaskarżanie uchwał zarządów i rad nadzorczych spółek kapitałowych. Przegląd Prawa Handlowego, (11), 4-18.

Stefaniak, A. (2009). Prawo spółdzielcze oraz ustawa o spółdzielniach mieszkaniowych. Warszawa: Oficyna Wydawnicza Spółdzielni Pracy „Delta”.

Szczurowski, T. (2007). Nieistniejące uchwały zgromadzenia spółki kapitałowej. Monitor Prawniczy, (6), 303-308.

Szumański, A. (2008). W: S. Sołtysiński, A. Szajkowski, A. Szumański, J. Szwaja. Kodeks spółek handlowych (t. 3). Komentarz do artykułów 301-458. Warszawa: C.H. Beck.

Szwaja, A. (2013). W: S. Sołtysiński (red.). Kodeks spótek handlowych. Spótka akcyjna. Komentarz do artykutów 301-490. Warszawa: C.H. Beck.

Tofel, M. S. (2007). Uchwały nieistniejące na gruncie kodeksu spółek handlowych. Prawo Spółek, (2), 69-82.

Wolter, A., Ignatowicz, J., Stefaniuk, K. (1998). Prawo cywilne. Zarys części ogólnej. Warszawa: PWN.

Wolter, A., Ignatowicz, J., Stefaniuk, K. (2018). Prawo cywilne. Zarys części ogólnej. Warszawa: Wolters Kluwer. 